\title{
Are Cardiovascular Disease (CVD) Risk Assessment and Management Programmes Cost Effective? A Systematic Review
}

\author{
John Tayu Lee ${ }^{12}$ \\ Kenny D Lawson ${ }^{34}$ \\ Yizhou Wan ${ }^{1}$ \\ Azeem Majeed ${ }^{1}$ \\ Stephen Morris ${ }^{4}$ \\ Michael Soljak ${ }^{1}$ \\ Christopher Millett ${ }^{1}$
}

${ }^{1}$ Department of Primary Care and Public Health, School of Public Health, Imperial College London, London, UK

${ }^{2}$ Saw Swee Hock School of Public Health, National University of Singapore, Singapore

${ }^{3}$ Centre for Health Research, School of Medicine, Western Sydney University, Sydney, Australia

${ }^{4}$ Centre for Research Excellence in Chronic Disease Prevention, Public Health and Tropical Medicine, James Cook University, Cairns, Australia

${ }^{4}$ Department of Applied Health Research, University College London, London, UK

\section{Word count}

Abstract: 249

Main text: 3805

Figures: 1

Tables: 1

Appendix Tables: 3 


\section{ABSTRACT}

\section{Objective}

The World Health Organization recommends that countries implement population-wide cardiovascular disease (CVD) risk assessment and management programmes. The aim of this study was to conduct a systematic review to evaluate whether this recommendation is supported by cost-effectiveness evidence.

\section{Methods}

Published economic evaluations were identified via electronic medical and social science databases (including Medline, Web of Science, and the NHS Economic Evaluation Database) from inception to March 2016. Study quality was evaluated using a modified version of the Consolidated Health Economic Evaluation Reporting Standards.

\section{Results}

14 economic evaluations were included: five studies based on randomised controlled trials, seven studies based on observational studies and two studies using hypothetical modelling synthesizing secondary data. Trial based studies measured CVD risk factor changes over 1 to 3 years, with modelled projections of longer term events. Programmes were either not, or only, cost-effective under non-verified assumptions such as sustained risk factor changes. Most observational and hypothetical studies suggested programmes were likely to be costeffective; however, study deigns are subject to bias and subsequent empirical evidence has contradicted key assumptions. No studies assessed impacts on inequalities.

\section{Conclusion}

Recommendations for population-wide risk assessment and management programmes lack a robust, real world, evidence basis. Given implementation is resource intensive there is a need for robust economic evaluation, ideally conducted alongside trials, to assess cost effectiveness. Further, the efficiency and equity impact of different delivery models should be investigated, and also the combination of targeted screening with whole population interventions recognising that there multiple approaches to prevention. 


\section{INTRODUCTION}

Cardiovascular disease (CVD), type 2 diabetes, and kidney disease are major causes of mortality worldwide ${ }^{1}$. These diseases share common modifiable risk factors that include smoking, raised blood pressure, obesity, and physical inactivity ${ }^{2}$. CVD alone accounted for 17.5 million deaths in 2012, representing $31 \%$ of all global deaths ${ }^{3}$. The prevalence of these conditions is increasing globally due to aging population and an increasing prevalence of risk factors such as obesity, posing major challenges to achieve the $25 \times 25$ non-communicable disease targets set by the World Health Organization $(\mathrm{WHO})^{4}$.

Many CVD events are preventable through changes in behavioural risk factors such as smoking and diet and pharmacological interventions. Clinical guidelines in Europe and several other countries support population wide programmes to assess and manage cardiovascular risk in individuals without pre-existing disease ${ }^{56}$. These consist of two sequential elements: (i) risk assessment of the adult population using a risk tool to assess global risk score. Individuals are then categorized into low, medium or high risk; (ii) referral to appropriate life style and pharmaceutical intervention in an effort to modify relevant risk factors. Examples of national CVD risk assessment and management programme include the NHS Health Check programme in England ${ }^{7}$, Keep Well in Scotland ${ }^{8}$ and More heart and diabetes checks in New Zealand9.

For primary and secondary prevention of CVD, the WHO recommends implementation of cardiovascular risk assessment programmes in low resource settings ${ }^{1011}$. For example, the WHO Package of Essential Noncommunicable (PEN) Disease includes CVD risk assessment and management as an integral part of prevention strategies for noncommunicable disease management ${ }^{10}$. Despite the growing enthusiasm for implementing these population-wide programmes worldwide there is on-going debate regarding whether these are cost effective, concern that health inequalities may increase, and whether screening should be prioritised and implemented in routine practice, especially given there are multiple potential prevention approaches ${ }^{12-14}$. The aim of this study was to conduct a systematic review to assess the cost effectiveness of CVD risk assessment and management programmes, hereon termed screening programmes. 


\section{METHODS}

We followed the methods detailed in a peer-reviewed systematic review protocol that is registered with PROSPERO (registration CRD 42014009470).

\section{Search strategy, inclusion criteria, and study selection}

We identified studies that conducted an economic evaluation of CVD risk assessment and management programmes, which included measuring multifactorial risk (including blood pressure, BMI, and smoking status) and referral to appropriate lifestyle and pharmaceutical interventions ${ }^{6} 15$.

We retrieved articles by searching through the following databases; Medline, EMBASE, Web of Science, Cochrane Database of Systematic Reviews, Centre for Reviews and Dissemination databases, DARE (Database of Abstracts of Reviews of Effects), NHS EED (NHS Economic Evaluation Database), and HTA database (Health Technology Assessments). We created a search strategy involving keywords and subject headings tailored to each databases. The key words were:

- Identifying diseases: "vascular disease", "cardiovascular disease", "coronary heart disease", "myocardial infarction", "cardiovascular events", "blood pressure", "hypertension", "hypercholesterolemia", "diabetes", "stroke", "kidney disease", and "chronic disease".

- Identifying economic evaluation: "economic evaluation", "quality-adjusted life years", "costbenefit", "cost-effectiveness", "cost-consequences", and "cost-utility".

- Identifying interventions: "risk factor", "health check", "community", "prevention", "intervention program", "general practice", "primary care", "health education", "health promotion", "lifestyle intervention", "smoking cessation", "diet", "obesity", and "weight".

\section{Inclusion and Exclusion Criteria}

We included all types of economic evaluation studies including cost-effectiveness, costutility, and cost-benefit analyses. Included studies had a variety of outcome measures including: risk factors, CVD outcomes, utility (economic measure of morbidity), life years, event-free time, disability adjusted life years (DALYs), quality adjusted life years (QALYs), and studies with a net monetary impact (where all outcomes are converted into monetary terms). 
Our searches covered all published research up to the last search performed in March 2016.

Two reviewers (YW and JTL) independently screened articles by title and subsequently by abstract to select articles for further review. Full texts of articles were then retrieved and reference lists were manually searched to check for additional articles. All disagreements were resolved by consensus or by reference to the third reviewer (CM).

Data were extracted from selected studies into data sheets with the following information included: 1) Intervention and risk factors targeted. 2) Population and settings. 3) Outcome and costs variables included. 4) Results from economic evaluation.

As there is no standard quality assessment tools for cost-effectiveness analysis, we employed a modified version of the Consolidated Health Economic Evaluation Reporting Standards (CHEERS) ${ }^{16}$ to evaluate the reporting quality of the studies included (see web appendix 2). We used arbitrary cut-offs to categorise studies into high/moderate/low quality. Studies with more than two thirds of items scored as done were defined as high quality, studies between one and two thirds were scored as moderate quality, and studies with less than one third were defined as low quality.

In reporting the results, we first grouped studies by study design and the main source of data, including: (i) studies based on trial evaluation evidence; (ii) studies based on observational evidence; and (iii) studies that were hypothetical modelling studies, where there was not an evaluation of an actual programme, but where multiple secondary data sources where used and synthesized to generate 'what if' analyses. Within each group studies were described in reverse chronological order. For (i) we also reported whether an economic evaluation was conducted alongside the trial itself, with separate reporting of 'within' trial' results and longer term modelling using the trial outcomes. Quality of studies were ranked using the modified CHEERS tool described above. Due to heterogeneity in the study design, population, and outcome measures reported, no meta-analysis was conducted, instead we provided a critical assessment of each study. 


\section{RESULTS}

Figure 1 summarises search results in a PRISMA flowchart. In total, 9207 articles were identified through the search process and screened based on the title and abstract, and of these, 123 full-text articles were assessed for eligibility. 14 primary articles met the eligibility criteria were included in the final review.

-Figure 1-

\section{Characteristics of the selected studies}

14 economic evaluations met the inclusion and exclusion criteria and were included in the review. Of these, five studies were based on randomised controlled trial evidence ${ }^{17-21}$, seven studies were based on observations evidence ${ }^{22-27}$, and two were based on hypothetical modelling 2829 .

In terms of the population studied, 10 economic evaluations originated from Europe ${ }^{17-2127-29}$, two from Israel ${ }^{25} 26$, and two from the United States ${ }^{2324}$. None of the studies were conducted in low and middle income settings. Most studies were categorised as middle or low quality except six recent studies which were graded as high quality (web appendix table 2).

Most trials had a follow up less than 3 years and none had CVD events as their primary outcome measure. Modelling was used to project longer term events and costs using trial findings of changes in risk factors. The most commonly used economic measures were incremental costs per life-years gained (LYG) and incremental costs per quality-adjusted life year (QALY) gained. A detailed description of the studies is presented in table 1 and web appendix table 3.

\section{-Table 1-}

\section{Intervention and risk factors targeted}

Although all interventions involved a general health check focused on modifiable cardiovascular risk factors, there was substantial variation in the individual risk factors assessed (see web appendix table 3). Risk factors most commonly assessed were blood pressure, body mass index (BMI), smoking status and cholesterol. Many interventions assessed additional risk factors including blood glucose, family history of CVD, alcohol 
consumption, diet and physical activity. There was also substantial variation how individuals were prioritized for treatment and which interventions were offered. In general, most interventions include advice, such as diet and physical activity, and pharmaceuticals.

\section{Cost-effectiveness}

Findings from trial based studies

EUROACTION ${ }^{20}$ was a matched, paired cluster randomised controlled trial of a nurse-lead CVD risk assessment and management programme in six European countries (Denmark, Italy, Netherlands, Poland, Spain and UK) conducted during 2003-2004. The programme include a CVD risk assessment followed by pharmaceutical and behavioural as appropriate. The trial measured individual risk factors such as blood pressure, BMI, cholesterol and glucose level etc., and has follow-up period of one year. Mistry et al (2012) undertook an economic evaluation and modelled possible effect on CVD events for the next 10 years, assuming intervention effect persist for 0 through to 10 additional years (11-year time horizon), after which they reverted to their individual CVD risk factor levels at the start of the study (adjusted for age). Their results suggested, after adjusting for individuals' baseline characteristics, the intervention was dominated by the usual care in each year of projections (i.e. the intervention arm has higher costs but lower QALYS) and is unlikely to be costeffective. A separate analysis of the Polish component of the EUROACTION program suggests that the intervention may have been cost-effective in that setting ${ }^{19}$. However, the results are sensitive to model assumptions such as duration of the intervention effects which needed to last at least ten years for the intervention to be cost-effective.

Oxcheck and the British Family Heart studies (BFHS) ${ }^{17} 18{ }^{30}$ were randomised controlled trials based in UK conducted in the 1990s. The two studies recruited middle aged men and women (aged 35-64 in Oxcheck, and 40-59 in BFHS). Oxcheck and BFHS included nurseled CVD risk assessment followed by appropriate lifestyle advice and drug intervention in general practice. The follow-up period for these two trials were one (BFHS) and three (Oxcheck) years of respectively, with modest changes in risk factors. Wonderling et al $(1996 a, b)$ investigated the effectiveness and cost-effectiveness of these two interventions using life-years gain (LYG) as the main outcome measures. Their results suggested the overall reduction in coronary risk was estimated to be around $13 \%$ to $20 \%$ in the Oxcheck study and $12 \%$ in the British Family Heart Study, and the Oxcheck programme was only cost-effective if the intervention effect lasted at least five years, and it was 10 years in BFHS.

Using information from the participants of the Oxcheck trial, Field $(1995)^{21}$ compared the cost-effectiveness of six CVD risk factors screening strategies; 1) Blood pressure and 
medical history, 2) + smoking, 3) + height and weight, 4) + diet, 5) + family history, 6) + blood cholesterol. This study found the most basic screening strategy was most costeffective, with increasing incremental costs per life year gained as the strategies become more comprehensive. Also, their results suggested the interventions were more cost effective if it targeted to high risk groups such as older men.

\section{Findings from observational studies}

The KardioPro is a risk assessment and management programme in Germany which targeted persons aged 45 years and above, as well as individuals with coronary heart disease (CHD). Patients with high risk were prescribed medication and risk factors were managed according to European guidelines. Aljutaili et al (2014) assessed the costeffectiveness of the intervention using maximum of four years follow-up data. Instead of using QALY or LYG as outcome measures, the primary outcome measured in this study was event-free days for death (all causes), myocardial infarction (MI) and stroke. The results of the study suggested the intervention was associated with gain of event-free days and it was highest in high CHD risk groups and lowest in low CHD risk group. In the cost-effectiveness analysis, their results reveal a wide range of cost-effectiveness ratios, ranging from $€ 20,901$ (high CHD risk) to $€ 186,074$ (low CHD risk) per event-free year. Overall they conclude the intervention would be more cost-effective if it were targeted in high risk groups, including those with existing CHD.

The Ashkelon Hypertension Detection and Control Program (AHDC) and Israeli Blood Pressure Control program (IBPC) were risk assessment programmes in Israel. Yosefy et al (2003 a, b) evaluated the cost-effectiveness of the intervention using reduction in CVD events as the primary outcome measures. Their study found both interventions were cost saving (i.e highly cost-effective) as the cost-offset due to improved health far outweighed the cost of the intervention. It is worth noting that the study applied a simple before and after comparison study design when assessing the effectiveness of the programme, therefore, the effectiveness of the intervention could be biased.

The WISEWOMAN programme was a risk assessment intervention targeted at low income, underinsured and uninsured women aged 40-64 years in the US. The intervention included CVD risk assessment followed by appropriate lifestyle advice to develop a healthier diet, increase physical activity, and quit tobacco use. Finkelstein et al (2006) evaluated the costeffectiveness of the intervention using one year follow-up data of changes in risk factors and modelled through 10 year probability of developing coronary heart disease (CHD). Their results yield a large variation in cost-effectiveness ratio under different assumptions. For 
example, the cost-effectiveness ratio was $\$ 4400$ per discounted life-year gained under the best case scenario (the intervention effect sustained life-long), but the figure increased to $\$ 133,500$ in the worse scenarios (the intervention effect only sustained for one year, and other assumptions on the missing data).

Finkelstein et al (2002) further compared the cost-effectiveness of the WISEWOMAN programme with different intensity of follow up treatment: the minimum intervention (MI) and the enhanced intervention (EI). The minimum intervention included risk factor assessment and a one-on-one counselling session. The enhanced intervention included all the activities in the minimum intervention and other interventions such as further counselling sessions and group intervention activities to improve physical activity levels and nutrition. The study results did not suggest $\mathrm{El}$ is more effective and cost-effective than $\mathrm{MI}$.

The Norsjo risk assessment programme was implemented in Sweden during 1985-1990. The intervention invited men and women aged 30-60 years for risk assessment followed by appropriate advice. Without a control group, Lindholm et al (1996) evaluated the effectiveness of the intervention by comparing changes in risk factors for the study population with those residing in neighbouring region over the study period. Their results suggested the intervention was highly cost-effective or even cost-saving. However, the observational data are prone to bias, the studies included lacked a control groups, and so in the absence of individual patient data it is difficult to confidently attribute changes in CVD risk and event to the programme itself, rather than general secular changes.

\section{Findings from economic modelling studies}

Schuetz et al (2013) simulated the likely cost-effectiveness if an NHS Health Check programme was implemented across 6 European countries: Denmark, France, Germany, Italy, Poland and UK. A hypothetical cohort of individuals aged 40-74 years were offered screening every 5 years. The model assumed population characteristics derived from US data, and also simulated health services in each country. The cost of screening was not included in the modelling. Individuals were screened and prioritized for treatment on the basis of inflated single risk factors, rather than using a global risk score. Cost per QALY was estimated over a 30 year time horizon. Results suggest that the screening programme would likely be cost effective with a cost per QALY ranging from 14,903 to cost saving. Sensitivity and scenario analysis untaken, where it was found that pre-screening strategies that targeted known high groups, such as the obese were more cost effective. 
The NHS Health Check in England began in 2009 and invites 40-74 year olds to a general additional screening conditional upon patient history. GPs are advised to follow clinical guidelines to prioritise and treat patients using pharmaceutical and behavioural intervention, as appropriate. The UK Department of Health ${ }^{27}$ simulated potential cost-effectiveness of the programme by assuming risk factors distributions in the population, and varying assumptions regarding costs, uptake, compliance, attribution (no formal control group was included), costs, and sustainability of treatment (citing secondary studies). Cost per QALY was estimated over the lifetime of individuals. Results suggest that the screening programme would likely be highly cost-effective, with a mean cost per QALY of $£ 2,480(£ 2,417$ - 22,617$)$ Sensitivity and scenario analysis was undertaken with the programme still likely to be cost effective.

\section{DISCUSSION}

\section{Summary and interpretation of findings}

The WHO and several national clinical guidelines recommend population wide CVD risk assessment and management programmes, consisting of estimating global CVD risk and onward referral to appropriate pharmaceutical and lifestyle interventions ${ }^{1031}$. However, there is a lack of robust, real-world, economic evidence regarding the cost effectiveness and inequality impact of population-wide screening programmes.

We found 14 studies assessing the cost-effectiveness of the intervention, of which five studies based on randomised controlled trials, seven studies based on observational studies and two studies using hypothetical modelling simulate "what-if" scenarios. No meta-analysis could be conducted given the heterogeneity between studies, such as variation in populations, screening approaches and interventions offered.

Of the three randomised control trials included in this review, a single study conducted an economic evaluation alongside a clinical trial to ensure appropriate outcomes and costs were collected ${ }^{20}$. The screening programme was not cost-effective, either over the one year duration of the trial, or from modelled projections over 10 years to allow for CVD events to emerge. Other economic studies (over 20 years old) were based upon RCTs that measured risk factor changes, with modelled projections providing tentative evidence that programmes may be cost-effective if trial results continued without change for at least ten years. In contrast to RCTs, most observational studies suggested that screening programmes are cost-effective. However, many observational studies employed simple pre-post study 
designs, without a control group, and the descriptions of the modelling approaches often lacked detail. Findings from both hypothetical modelling studies found that screening is likely to be highly cost-effective. However, these hypothetical studies are solely based on collating multiple secondary data sources and/or rely on key assumptions regarding model parameters, such as costs, uptake, compliance, attribution (given no control groups). Recent systematic reviews have cast doubt on applying key assumptions, and emerging evidence from England's NHS Health Checks programme have contradicted key assumptions ${ }^{32} 33$, where uptake of the programme was found to be $21 \%$ in contrast to the $75 \%$ assumed in the modelling projections ${ }^{7}$. Further, doubts remain regarding the predictive accuracy in the epidemiological modelling from risk factors to clinical events ${ }^{34}$.

All of the included studies were undertaken in high income settings such as Europe and US. There is a lack of evidence from low and middle income settings where $80 \%$ of the global non-communicable disease (NCD) mortality occur ${ }^{3}$. No studies assessed impacts on health inequalities in the population.

\section{Research recommendations}

Given the absence of robust evidence regarding cost effectiveness of screening programmes and the impacts on health inequalities, it seems prudent to recommend that economic evaluation should be conducted. For example, the overall cost of the UK's Health Checks programme is estimated to be $£ 243$ million each year and intended to run in perpetuity ${ }^{28}$. Conducting evaluation is not a costless exercise and so there may be merit in formalizing the (economic) value of information from further research to reduce uncertainty regarding cost effectiveness. The need for robust evidence is perhaps especially important for low and middle countries faced with multiple challenges and yet have fewest resources to implement programmes ${ }^{31}$. Ideally evaluation should be alongside clinical trials to ensure appropriate outcomes and costs are collected, and with sufficient follow-up to provide confidence in key assumptions such as uptake and compliance behaviour. Recent studies have highlighted the importance of finding innovative ways to deliver CVD risk screening at lower cost in resources poor settings ${ }^{38} 39$.

Economic modelling will remain important in future research to project results beyond trial duration to estimate events, costs and cost effectiveness. Nonetheless, modelling approaches can be improved and follow international modelling guidance ${ }^{35}$. This includes, for instance, validating the modelling process, assumptions used and predictions made where possible. Transparency in reporting modelling approaches would also help comparability of findings across settings and improve the confidence in results produced. 
Further, while screening programmes are focussed on CVD, the interventions target risk factors (such as smoking and cholesterol) that are generic to a range of diseases (such as cancers and respiratory diseases), and so trials and modelling can usefully account for nonCVD events. A related issue is that no economic models have assessed the full impacts on extending life expectancy on quality of life and health service costs from the expected increase in comorbidities.

Future studies can usefully test not only the impact of population-wide screening but also explore the efficiency and equity impact of different screening approaches. Research has suggested that rather than screen the whole population from 40-74 years it may be more cost effective to include a pre-screening element given that high risk individuals are concentrated in known and identifiable groups such individuals who are older, have a family history, and living within deprived areas ${ }^{36}{ }^{37}$. Further, economic analysis can usefully explore whether the cost effectiveness results of the programme (screening plus multiple interventions) is actually driven by specific elements and perhaps not everything included in the programme is cost effective. Only one study included in this review (Finkelstein et al 2012) evaluated the cost-effectiveness of risk assessment programme with different followup interview. For instance, it may be that smoking interventions, known to be highly cost effective, are driving the results and programmes could be made more efficient. Finally, an important issue is regarding implementation and whether the primary care system can absorb extra work load, or whether there is scope to drop and replace existing activities. Recent studies have highlighted the importance of finding innovative ways to deliver CVD risk screening at lower cost in resources poor settings ${ }^{38} 39$.

\section{Policy Implications}

With many countries having begun or considering implementing CVD risk assessment programmes, it is important that these interventions are properly tested to assess whether they are a cost effective use of resources, and to assess impacts on health inequalities. Policy should be aware of the possibility of improving the efficiency of screening approaches and delivery mechanisms, and also that that may be more optimal to combine targeted screening on known high risk groups with population approaches such as fiscal policies and legislative changes ${ }^{40}$. This may be especially important for low and middle-income countries where the bulk of the global CVD burden lies, and where health care resources are fewest. Overall, the primary prevention of CVD is likely to remain a high policy priority globally, and evidence based policymaking necessitates that the approach should be based on robust evidence of effectiveness, cost effectiveness and impacts on health inequalities. 


\section{Conclusion}

Recommendations for population-wide risk assessment and management programmes lack a robust, real world, evidence basis. Given implementation is resource intensive there is a need for robust economic evaluation, ideally conducted alongside trials, to assess cost effectiveness. Further, the efficiency and equity impact of different delivery models should be investigated, and also the combination of targeted screening with whole population interventions recognising that there multiple approaches to prevention. 


\section{FUNDING}

CM is funded by a NIHR Research Professorship award. The Department of Primary Care \& Public Health at Imperial College is grateful for support from the National Institute for Health Research Biomedical Research Centre Funding scheme, the National Institute for Health Research Collaboration for Leadership in Applied Health Research and Care scheme, and the Imperial Centre for Patient Safety and Service Quality.

\section{ACKNOWLEDGEMENT}

We would like to thank Kiara Chang and Andrew Dalton for helpful comments in the draft of the paper.

\section{ETHICS APPROVAL}

Not required

\section{AUTHOR CONTRIBUTIONS}

JTL, CM conceived the article. YW, JTL performed the literature search. JTL, YW, KL collected data from individual studies and interpreted the data. JTL, KL, YW, CM wrote the first draft of the paper. KL, SM, and AM revised the first and subsequent drafts. All authors contributed to interpretation of the findings and revised the manuscript for important intellectual content. 


\section{REFERENCE}

1. Lozano R, Naghavi M, Foreman K, et al. Global and regional mortality from 235 causes of death for 20 age groups in 1990 and 2010: a systematic analysis for the Global Burden of Disease Study 2010. The Lancet 2012;380(9859):2095-128.

2. Collins GS, Altman DG. An independent and external validation of QRISK2 cardiovascular disease risk score: a prospective open cohort study. BMJ 2010;340.

3. WHO Global status report on noncommunicable diseases 2014. World Health Organization.

4. Atun R. Decisive action to end apathy and achieve $25 \times 25$ NCD targets. The Lancet 2014.

5. Perk J, De Backer G, Gohlke H, et al. European Guidelines on cardiovascular disease prevention in clinical practice (version 2012). The Fifth Joint Task Force of the European Society of Cardiology and Other Societies on Cardiovascular Disease Prevention in Clinical Practice (constituted by representatives of nine societies and by invited experts). Eur Heart J 2012;33.

6. Encouraging people to have NHS Health Checks and supporting them to reduce risk factors. National Institute for Health and Care Excellence (NICE) https://www.nice.org.uk/advice/lgb15/chapter/introduction.

7. Chang KC-M, Soljak M, Lee JT, et al. Coverage of a national cardiovascular risk assessment and management programme (NHS Health Check): Retrospective database study. Preventive Medicine 2015;78(0):1-8.

8. The impact of keep well: An evaluation of the Keep Well programme from 2006 to 2012. NHS Scotland http://www.healthscotland.com/uploads/documents/23893Keep Well Impact Evaluation report.pdf.

9. Ministry of Health. Health Targets: More heart and diabetes checks. [Online]. Available from: http://www.health.govt.nz/new-zealand-health-system/health-targets/about-healthtargets/health-targets-more-heart-and-diabetes-checks [Accessed 24th March 2015]. Secondary Health Targets: More heart and diabetes checks. [Online]. Available from: http://www.health.govt.nz/new-zealand-health-system/health-targets/about-healthtargets/health-targets-more-heart-and-diabetes-checks [Accessed 24th March 2015].

10. Package of essential NCD interventions for primary health care: cancer, diabetes, heart disease and stroke, chronic respiratory disease. World Health Organisation 2010. http://www.who.int/cardiovascular diseases/publications/pen2010/en/.

11. Prevention and Control of Noncommunicable Diseases: Guidelines for primary health care in lowresouce settings. World Health Organisation 2012 http://www.who.int/nmh/publications/phc2012/en/.

12. Barton $P$, Andronis L, Briggs A, et al. Effectiveness and cost effectiveness of cardiovascular disease prevention in whole populations: modelling study. BMJ 2011;343.

13. Capewell S, McCartney M, Holland W. Invited debate: NHS Health Checks-a naked emperor? Journal of Public Health 2015;37(2):187-92.

14. Jackson $R$, Wells $S$, Rodgers $A$. Will screening individuals at high risk of cardiovascular events deliver large benefits? Yes. BMJ 2008;337.

15. Chang KC-M, Lee JT, Vamos EP, et al. Impact of the National Health Service Health Check on cardiovascular disease risk: a difference-in-differences matching analysis. Canadian Medical Association Journal 2016.

16. Husereau D, Drummond M, Petrou S, et al. Consolidated Health Economic Evaluation Reporting Standards (CHEERS) statement. BMJ 2013;346.

17. Wonderling D, Langham S, Buxton $M$, et al. What can be concluded from the Oxcheck and British family heart studies: commentary on cost effectiveness analyses. Bmj 1996;312(7041):12748.

18. Wonderling $D$, McDermott $C$, Buxton $M$, et al. Costs and cost effectiveness of cardiovascular screening and intervention: the British family heart study. BMJ 1996;312(7041):1269-73. 
19. Šović $N$, Pająk A, Jankowski P, et al. Cost-effectiveness of a cardiovascular disease primary prevention programme in a primary health care setting. Results of the Polish part of the EUROACTION project. Kardiologia Polska 2013;71:702-11.

20. Mistry H, Morris S, Dyer $\mathrm{M}$, et al. Cost-effectiveness of a European preventive cardiology programme in primary care: a Markov modelling approach. BMJ Open 2012;2(5).

21. Field K, Thorogood M, Silagy C, et al. Strategies for reducing coronary risk factors in primary care: which is most cost effective? BMJ 1995;310.

22. Lindholm L, Rosén $M$, Weinehall $L$, et al. Cost effectiveness and equity of a community based cardiovascular disease prevention programme in Norsjö, Sweden. Journal of Epidemiology and Community Health 1996;50(2):190-95.

23. Finkelstein EA, Khavjou O, Will JC. Cost-effectiveness of WISEWOMAN, a program aimed at reducing heart disease risk among low-income women. Journal of Women's Health 2006;15:379-89.

24. Finkelstein EA, Troped PJ, Will JC, et al. Cost-Effectiveness of a Cardiovascular Disease Risk Reduction Program Aimed at Financially Vulnerable Women: The Massachusetts WISEWOMAN Project Journal of Women's Health \& Gender-Based Medicine 2002;11:51926.

25. Yosefy C, Dicker D, Viskoper J, et al. The Ashkelon Hypertension Detection and Control Program (AHDC Program): a community approach to reducing cardiovascular mortality. Prev Med 2003;37(6):571 - 6.

26. Yosefy C, Ginsberg G, Dicker D, et al. Risk factor profile and achievement of treatment goals among hypertensive patients from the Israeli Blood Pressure Control (IBPC) program - initial cost utility analysis. Blood Press 2003;12(4):225 - 31.

27. Aljutaili M, Becker C, Witt S, et al. Should health insurers target prevention of cardiovascular disease?: a cost-effectiveness analysis of an individualised programme in Germany based on routine data. BMC Health Services Research 2014;14(1):1-10.

28. Economic Modelling for Vascular Checks. Department of Health (2008). Accessed http://www.healthcheck.nhs.uk/document.php?o=225 in April 2016.

29. Schuetz CA, Alperin P, Guda S, et al. A Standardized Vascular Disease Health Check in Europe: A Cost-Effectiveness Analysis. PLoS ONE 2013;8(7):e66454.

30. Langham S, Thorogood M, Normand C, et al. Costs and cost effectiveness of health checks conducted by nurses in primary care: the Oxcheck study. BMJ 1996;312(7041):1265-68.

31. Modesti PA, Agostoni P, Agyemang C, et al. Cardiovascular risk assessment in low-resource settings: a consensus document of the European Society of Hypertension Working Group on Hypertension and Cardiovascular Risk in Low Resource Settings. Journal of Hypertension 2014;32(5):951-60.

32. Si S, Moss JR, Sullivan TR, et al. Effectiveness of general practice-based health checks: a systematic review and meta-analysis. British Journal of General Practice 2014;64(618):e47e53.

33. Krogsbøll LT, Jørgensen KJ, Larsen CG, et al. General health checks in adults for reducing morbidity and mortality from disease: Cochrane systematic review and meta-analysis. BMJ 2012;345.

34. Cooney MT, Dudina A, D'Agostino R, et al. Cardiovascular Risk-Estimation Systems in Primary Prevention: Do They Differ? Do They Make a Difference? Can We See the Future? Circulation 2010;122(3):300-10.

35. Caro JJ, Briggs AH, Siebert U, et al. Modeling Good Research Practices-Overview: A Report of the ISPOR-SMDM Modeling Good Research Practices Task Force-1. Medical Decision Making 2012;32(5):667-77.

36. Lawson KD, Fenwick EAL, Pell ACH, et al. Comparison of mass and targeted screening strategies for cardiovascular risk: simulation of the effectiveness, cost-effectiveness and coverage using a cross-sectional survey of 3921 people. Heart 2010;96(3):208-12. 
37. Baker J, Mitchell R, Lawson K, et al. Ethnic differences in the cost-effectiveness of targeted and mass screening for high cardiovascular risk in the UK: cross-sectional study. Heart 2013;99(23):1766-71.

38. Gaziano T, Abrahams-Gessel S, Surka S, et al. Cardiovascular Disease Screening By Community Health Workers Can Be Cost-Effective In Low-Resource Countries. Health Affairs 2015;34(9):1538-45.

39. Gaziano TA, Abrahams-Gessel S, Denman CA, et al. An assessment of community health workers' ability to screen for cardiovascular disease risk with a simple, non-invasive risk assessment instrument in Bangladesh, Guatemala, Mexico, and South Africa: an observational study. The Lancet Global Health 2015;3(9):e556-e63.

40. Zaman MJS, Jones MM. Strategies to screen and reduce vascular risk-putting statins in the tap water is not the answer. Heart 2010;96(3):177-78. 


\section{FIGURES and TABLES}

Figure 1- Flow diagram of study design
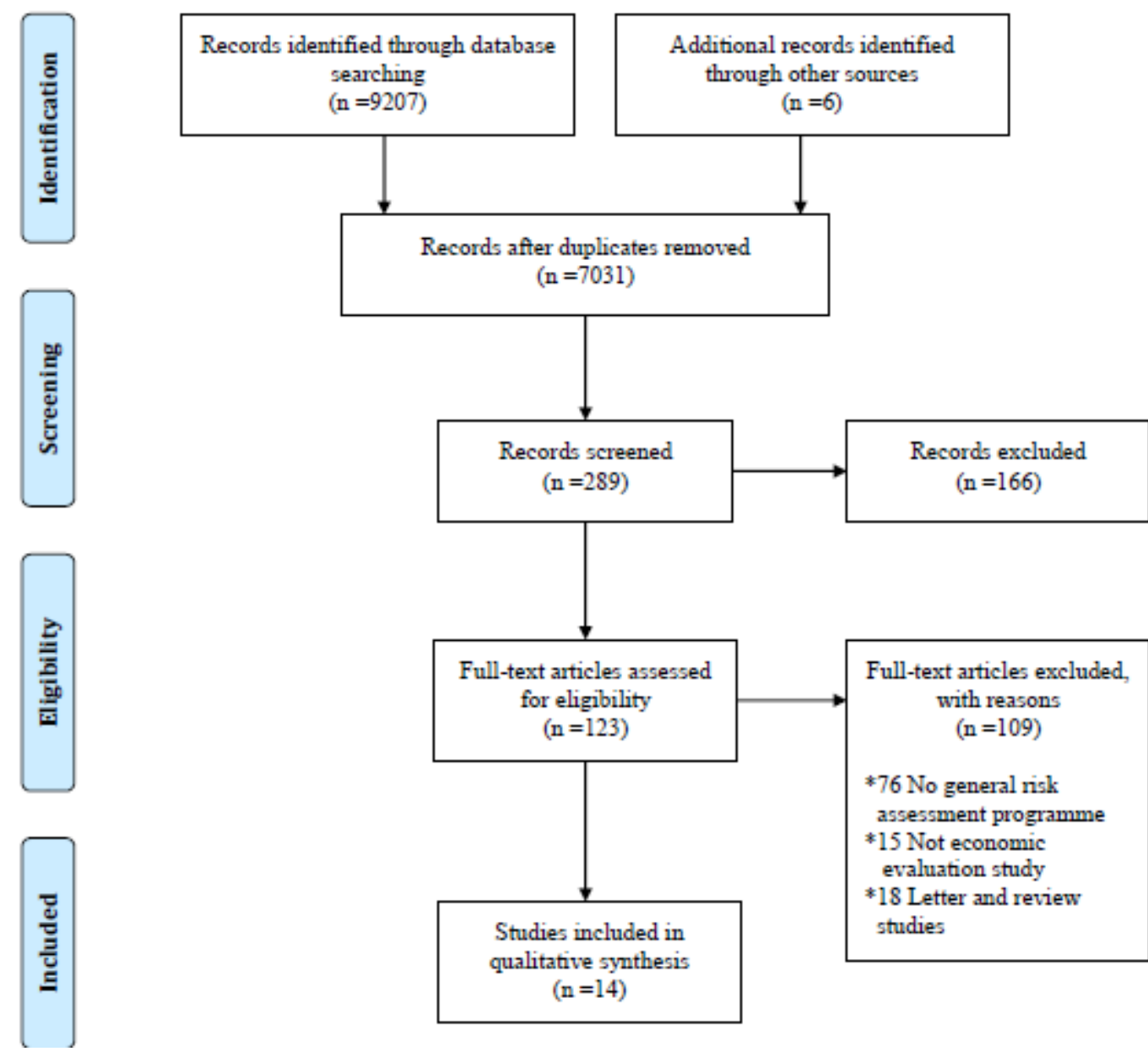

qualitative synthesis $(n=14)$ 
Table 1- Results for Included Studies

\begin{tabular}{|c|c|c|c|c|c|}
\hline $\begin{array}{c}\text { Study } \\
\text { Design }\end{array}$ & Reference & Intervention and risk factors targeted & Population and settings & Outcome and costs variables & Cost-effectiveness results \\
\hline $\begin{array}{l}\text { RCT } \\
\text { (Economic } \\
\text { evaluation } \\
\text { alongside } \\
\text { RCT) }\end{array}$ & $\begin{array}{l}\text { Sovic et al } \\
(2013) \\
\text { EUROACTION } \\
\text { component in }_{\text {Poland }^{19}}\end{array}$ & $\begin{array}{l}\text { This study is the Polish component of the } \\
\text { EUROACTION project. The description of } \\
\text { the EUROACTION project can be found in } \\
\text { Mistry et al (2012) of this table. }\end{array}$ & $\begin{array}{l}\text { A total of } 233 \text { men and women from the } \\
\text { intervention arm (average age of } 56.5 \text { ), and } \\
28 \text { individuals from the control arm (average } \\
\text { age of 57). }\end{array}$ & $\begin{array}{l}\text { Outcome measures: Quality adjusted life } \\
\text { years (QALY). One year follow up period } \\
\text { Costs variable: } \\
\text { (1) Costs of screening and tests } \\
\text { (2) Cost of drugs prescribed } \\
\text { (3) Cost of other health service use including } \\
\text { secondary care and medication }\end{array}$ & $\begin{array}{l}\text { Incremental cost-effectiveness ratio (ICER) } \\
\text { was } 19,524 \text { Poland Zloty for men and } 82,262 \\
\text { PLN for women. However, the results are } \\
\text { sensitive to model assumptions such as } \\
\text { changes of health states utilities and duration } \\
\text { of the intervention effects. }\end{array}$ \\
\hline $\begin{array}{l}\text { RCT } \\
\text { (Economic } \\
\text { evaluation } \\
\text { alongside } \\
\text { RCT) }\end{array}$ & $\begin{array}{l}\text { Mistry et al } \\
(2012) \\
\text { EUROACTION }\end{array}$ & $\begin{array}{l}\text { Nurse-led risk assessments programme } \\
\text { measuring CVD risk factors. Each patient was } \\
\text { given a personal record card to record } \\
\text { lifestyle and risk factor goals, medications } \\
\text { and appointments. }\end{array}$ & $\begin{array}{l}\text { EUROACTION study was conducted } \\
\text { between } 2003-2006 \text { in six European } \\
\text { countries. In total, } 1019 \text { patients in the } \\
\text { intervention group, and } 1005 \text { in the control } \\
\text { group. }\end{array}$ & $\begin{array}{l}\text { Outcome measures: Quality adjusted life } \\
\text { years (QALYS). One year follow up period } \\
\text { Costs variable: } \\
\text { (1) Costs of screening and tests } \\
\text { (2) Cost of drugs prescribed } \\
\text { (3) Cost of other health service use including } \\
\text { secondary care and medication }\end{array}$ & $\begin{array}{l}\text { The intervention group is dominated by the } \\
\text { usual care group (i.e higher costs but lower } \\
\text { QALYs) in the fully adjusted model. }\end{array}$ \\
\hline RCT & $\begin{array}{l}\text { Wonderling et } \\
\text { al. (1996a) The } \\
\text { British Family } \\
\text { Heart Study }\end{array}$ & $\begin{array}{l}\text { Risk assessment involved multiple risk } \\
\text { factors. Risk stratified determined follow-up } \\
\text { from either every two months (the highest } \\
\text { risk group) to once a year (the lowest risk } \\
\text { group). }\end{array}$ & $\begin{array}{l}13 \text { general practices across UK in the } 1990 \text { s. } \\
\text { Intervention group: } 1767 \text { men aged } 40-59 \text { and } \\
1217 \text { women. Control group: } 2174 \text { men and } \\
1402 \text { women. }\end{array}$ & $\begin{array}{l}\text { Outcome measures: Coronary risk reduction. } \\
\text { One year follow up period. } \\
\text { Costs variable: } \\
\text { (1) Cost of screening and tests } \\
\text { (2) Cost of drugs prescribed } \\
\text { (3) Cost of other health service use }\end{array}$ & $\begin{array}{l}\text { The cost effectiveness was estimated at } £ 4.3 \\
\text { per } 1 \text { percentage reduction in coronary risk. }\end{array}$ \\
\hline $\mathrm{RCT}$ & $\begin{array}{l}\text { Wonderling } \\
\text { (1996b) } \\
\text { Oxcheck and } \\
\text { British Family } \\
\text { Heart Studies }\end{array}$ & Oxcheck and British Family Heart Study & $\begin{array}{l}\text { Population in Oxcheck and British Family } \\
\text { Heart Study }\end{array}$ & $\begin{array}{l}\text { Outcome measures: Life-years gain (LYG) } \\
\text { Costs variable: } \\
\text { Same as Oxcheck and BFHS }\end{array}$ & $\begin{array}{l}\text { Cost per life year gain ranged from } £ 34800 \\
\text { to } 11500 \text { for British family heart study, and } \\
\text { from } £ 29300 \text { to } £ 900 \text { for Oxcheck. }\end{array}$ \\
\hline RCT & $\begin{array}{l}\text { Field et al } \\
(1995)\end{array}$ & $\begin{array}{l}\text { This study simulated costs and cost- } \\
\text { effectiveness of } 6 \text { CVD risk factors screening } \\
\text { strategies; 1) Blood pressure and medical } \\
\text { history, 2) + smoking, 3) + height and weight, } \\
\text { 4) + diet, 5) + family history, 6) + blood } \\
\text { cholesterol. }\end{array}$ & $\begin{array}{l}\text { A modelling study based on population } \\
\text { attended OXCHECK trial in Bedfordshire in } \\
\text { 1993. The population studied was } 7840 \text { men } \\
\text { and women aged 35-64. }\end{array}$ & $\begin{array}{l}\text { Outcome measures: Life-years gain (LYG) } \\
\text { Costs variable: } \\
\text { (1) Cost of screening and tests } \\
\text { (2) Cost of drugs prescribed } \\
\text { (3) Cost of conducting intervention session }\end{array}$ & $\begin{array}{l}\text { The most basic screening strategy was most } \\
\text { cost effective, with increasing cost per life } \\
\text { year gain as the strategies become more } \\
\text { comprehensive. Interventions are more cost } \\
\text { effective in men than women, and in older } \\
\text { rather than younger population. }\end{array}$ \\
\hline
\end{tabular}




\section{Table 1 continued- Results for Included Studies}

\begin{tabular}{|c|c|c|c|c|c|}
\hline $\begin{array}{l}\text { Study } \\
\text { Design }\end{array}$ & Reference & Intervention and risk factors targeted & Population and settings & Outcome and costs variables & Cost-effectiveness results \\
\hline $\begin{array}{l}\text { Observational } \\
\text { Study }\end{array}$ & $\begin{array}{l}\text { Aljutaili et al } \\
\text { (2014) } \\
\text { KardioPro }\end{array}$ & $\begin{array}{l}\text { Risk assessment involved multiple risk } \\
\text { factors. Risk stratified followed by a tailored } \\
\text { lifestyle intervention and medical } \\
\text { interventions. }\end{array}$ & $\begin{array}{l}\text { Insured people aged } 45 \text { years and above, as } \\
\text { well as subjects with coronary heart disease. } \\
\text { All subjected were enrolled in KardioPro } \\
\text { intervention from 2007-2009 (13,116 } \\
\text { individuals). }\end{array}$ & $\begin{array}{l}\text { Outcome measures: 1) event free time for all- } \\
\text { cause mortality, acute myocardial infarction } \\
\text { and ischemic stroke } \\
\text { Cost included: } \\
\text { (1) Costs of screening and tests } \\
\text { (2) Medical costs associated with CVD events }\end{array}$ & $\begin{array}{l}\text { Estimates for cost per event-free year ranges } \\
\text { from } € 20,901 \text { (high CHD risk population) to } \\
€ 186,074 \text { (low CHD risk population). }\end{array}$ \\
\hline $\begin{array}{l}\text { Observational } \\
\text { Study }\end{array}$ & $\begin{array}{l}\text { Finkelstein et al } \\
\text { (2006) } \\
\text { WISEWOMEN }\end{array}$ & $\begin{array}{l}\text { WISEWOMAN project provided risk } \\
\text { assessment, and followed by a tailored } \\
\text { lifestyle intervention. }\end{array}$ & $\begin{array}{l}\text { The programmes targeted low income, } \\
\text { underinsured and uninsured women aged 40- } \\
64 \text {. This study used data from nine projects } \\
\text { across US from 2000-2003, with a total of } \\
3015 \text { women participants. }\end{array}$ & $\begin{array}{l}\text { Outcome measures: } 10 \text { year risk of coronary } \\
\text { heart disease; Life-years gained (LYG). One } \\
\text { year follow up period. } \\
\text { Costs variable: } \\
\text { (1) Cost of screening and tests } \\
\text { (2) Cost of conducting intervention sessions } \\
\text { (3) Cost of providing outreach }\end{array}$ & $\begin{array}{l}\$ 470 \text { to achieve an average of } 1 \text { percentage } \\
\text { point reduction in CHD risk, which translates } \\
\text { into a cost-effectiveness ratio of } \$ 4400 \text { per } \\
\text { life year gain. }\end{array}$ \\
\hline $\begin{array}{l}\text { Observational } \\
\text { Study }\end{array}$ & $\begin{array}{l}\text { Finkelstein et al } \\
\text { (2002) } \\
\text { WISEWOMAN }\end{array}$ & $\begin{array}{l}\text { Two levels of WISEWOMAN CVD } \\
\text { screening programme. The minimum } \\
\text { intervention included a risk factors screening } \\
\text { and one-on-one counselling session. The } \\
\text { enhanced intervention, which included all } \\
\text { these activities mentioned above and other } \\
\text { intervention activities such as further } \\
\text { counselling sessions and group intervention } \\
\text { activities etc. }\end{array}$ & $\begin{array}{l}\text { Low income, underinsured and uninsured } \\
\text { women in Massachusetts, US. } 819 \text { women } \\
\text { were recruited into the intervention group, } \\
\text { and } 767 \text { in the comparison group. }\end{array}$ & $\begin{array}{l}\text { Outcome measures: } 10 \text { year risk of coronary } \\
\text { heart disease. One year follow up period. } \\
\text { Costs variable: } \\
\text { (1) Cost of screening and tests } \\
\text { (2) Cost of conducting intervention sessions } \\
\text { (3) Cost of providing outreach }\end{array}$ & $\begin{array}{l}\text { There was a larger but not statistically } \\
\text { significant reduction in } 10 \text { year CHD risk for } \\
\text { those received intensive treatment compared } \\
\text { to normal treatment. The results suggested } \\
\$ 637 \text { to achieve a } 1 \text { percentage point decrease } \\
\text { in the } 10 \text { year probability of CHD, } \$ 5000 \text { for } \\
\text { one life-year gained. }\end{array}$ \\
\hline $\begin{array}{l}\text { Observational } \\
\text { Study }\end{array}$ & $\begin{array}{l}\text { Yosefy et al } \\
\text { (2003a) AHDC } \\
\text { Program }\end{array}$ & $\begin{array}{l}\text { CVD risks screening, and high risk patients } \\
\text { underwent an intensive CVD risk factor } \\
\text { control program. }\end{array}$ & $\begin{array}{l}\text { Ashkelon in Israel. During 1980-1990, the } \\
\text { program examined } 12002 \text { subjects ( } 6833 \text { Men } \\
\text { and } 5369 \text { Women) aged } 20-65 .\end{array}$ & $\begin{array}{l}\text { Outcome measures: 1) Standardized mortality } \\
\text { ratio 2) Life year gain } \\
\text { Costs variable: } \\
\text { (1) Overall programme costs } \\
\text { (2) Cost of other health service use }\end{array}$ & $\begin{array}{l}\text { After taking into account the cost saving due } \\
\text { to improved health, the cost of the programme } \\
\text { was offset by cost saving due to improved } \\
\text { health. }\end{array}$ \\
\hline $\begin{array}{l}\text { Observational } \\
\text { Study }\end{array}$ & $\begin{array}{l}\text { Yosefy et al } \\
\text { (2003b) IBPC } \\
\text { program }\end{array}$ & $\begin{array}{l}\text { Physicians recorded patients' risk factors and } \\
\text { medications for all patients with hypertension. }\end{array}$ & $\begin{array}{l}4948 \text { patients with hypertension (mean age of } \\
64.6 \text { ) from } 30 \text { general practice clinics across } \\
\text { Israel. The Israeli Blood Pressure Control } \\
\text { (IBPC) program was initiated in the year } \\
2000 \text {. }\end{array}$ & $\begin{array}{l}\text { Outcome measures: Acute myocardial } \\
\text { infarctions event } \\
\text { Costs variable: } \\
\text { (1) Costs of screening and tests } \\
\text { (2) Cost of drugs prescribed } \\
\text { (3) Cost of other health service use including } \\
\text { secondary care and medication }\end{array}$ & $\begin{array}{l}\text { The cost of the intervention was offset by cost } \\
\text { saving due to improved health, gives a net } \\
\text { saving of } \$ 977,993 \text {. }\end{array}$ \\
\hline
\end{tabular}


Table 1 continued- Results for Included Studies

\begin{tabular}{|c|c|c|c|c|c|}
\hline Study Design & Reference & Intervention and risk factors targeted & Population and settings & Outcome and costs variables & Cost-effectiveness results \\
\hline $\begin{array}{l}\text { Observational } \\
\text { Study }\end{array}$ & $\begin{array}{l}\text { Langham et } \\
\text { al. (1996) } \\
\text { The Oxcheck } \\
\text { Study }\end{array}$ & $\begin{array}{l}\text { Nurses performed checks with defined } \\
\text { protocol. Risk score used to stratify patients, } \\
\text { high risk patients returned for follow-up. }\end{array}$ & $\begin{array}{l}\text { Five general practices in Luton and Dunstable } \\
\text { in England during 1989-1993. Intervention } \\
\text { group: } 2205 \text { Men and Women aged 35-64. } \\
\text { Control group: comparable group of } 1916 \\
\text { individuals. }\end{array}$ & $\begin{array}{l}\text { Outcome measures: reduction in the relative } \\
\text { risk of cardiovascular disease. Three years } \\
\text { follow up period. } \\
\text { Costs variable: } \\
\text { (1) Costs of screening and tests } \\
\text { (2) Cost of drugs prescribed } \\
\text { (3) Cost of other health service use }\end{array}$ & $\begin{array}{l}\text { The overall reduction in coronary risk was } \\
\text { between } 13 \% \text { to } 20 \% \text {. Cost per } 1 \% \text { reduction } \\
\text { in coronary risk was between } £ 1.46 \text { and } £ 2.25 \text {. }\end{array}$ \\
\hline $\begin{array}{l}\text { Observational } \\
\quad \text { Study }\end{array}$ & $\begin{array}{l}\text { Lindholm et } \\
\text { al (1996) }\end{array}$ & $\begin{array}{l}\text { Nurses performed screening annually which } \\
\text { comprising of medical exam, lifestyle } \\
\text { questionnaire, advice on main risk factors for } \\
\text { cardiovascular disease. }\end{array}$ & $\begin{array}{l}\text { Norsjo, Sweden during } 1985-1990.5500 \\
\text { (men and women aged } 30-60 \text { years) were } \\
\text { invited for risk factor screening, and overall } \\
1498 \text { individual were screened. Control group } \\
\text { were those live in other countries in Sweden. }\end{array}$ & $\begin{array}{l}\text { Outcome measures: Life-years gain (LYG) } \\
\text { Costs variable: } \\
\text { (1) Cost of screening and tests } \\
\text { (2) Cost of other health service use including } \\
\text { secondary care } \\
\text { (3) Societal cost }\end{array}$ & $\begin{array}{l}\text { From societal perspective, cost per life year } \\
\text { gain ranged from } £ 14900 \text { to net saving. }\end{array}$ \\
\hline $\begin{array}{l}\text { Economic } \\
\text { Modelling }\end{array}$ & $\begin{array}{l}\text { Schuetz et al } \\
\text { (2013) }\end{array}$ & $\begin{array}{l}\text { Risk assessment involved multiple risk } \\
\text { factors. Risk stratified followed by a tailored } \\
\text { lifestyle intervention and medical } \\
\text { interventions. }\end{array}$ & $\begin{array}{l}\text { Population aged } 40-74 \text { years in } 6 \text { European } \\
\text { countries: Denmark, France, Germany, Italy, } \\
\text { Poland and UK }\end{array}$ & $\begin{array}{l}\text { Outcome measures: 1) Major adverse } \\
\text { cardiovascular events 2) Quality adjusted life } \\
\text { years (QALY). } \\
\text { Costs variable: } \\
\text { (1) Cost of screening and tests } \\
\text { (2) Costs of providing interventions } \\
\text { (3) Costs associated with vascular disease }\end{array}$ & $\begin{array}{l}\text { This study found the interventions are likely to } \\
\text { be cost-effective in most countries with cost } \\
\text { per QALY ranging from cost-saving in Poland } \\
\text { to } € 14903 \text { in France. The intervention would } \\
\text { be more cost-effective if targeted on higher } \\
\text { risk groups such as the elderly or overweight } \\
\text { population. }\end{array}$ \\
\hline $\begin{array}{l}\text { Economic } \\
\text { Modelling }\end{array}$ & $\begin{array}{l}\text { Department } \\
\text { of Health, } \\
\text { UK }\end{array}$ & $\begin{array}{l}\text { Risk assessment involved multiple risk } \\
\text { factors. Risk stratified followed by a tailored } \\
\text { lifestyle intervention and medical } \\
\text { interventions. }\end{array}$ & $\begin{array}{l}\text { Population aged } 40-74 \text { years in England, who } \\
\text { are not currently on a vascular disease register. }\end{array}$ & $\begin{array}{l}\text { Outcome measures: Quality adjusted life years } \\
\text { (QALYS). } \\
\text { Costs variable: } \\
\text { (1) Cost of screening and tests } \\
\text { (2) Life time cost after receiving interventions }\end{array}$ & $\begin{array}{l}\text { the intervention is highly cost-effective, with } \\
\text { an estimate of its cost per QALY of around } \\
£ 3,000\end{array}$ \\
\hline
\end{tabular}




\section{Web Appendix}

\section{Appendix Table 1- Consolidated Health Economic Evaluation Reporting Standards (CHEERS)}

\begin{tabular}{|c|c|}
\hline Section/item & Recommendation \\
\hline \multicolumn{2}{|l|}{ Title and abstract } \\
\hline 1. Title & $\begin{array}{l}\text { Identify the study as an economic evaluation or use more specific terms such as "cost- } \\
\text { effectiveness analysis", and describe the interventions compared. }\end{array}$ \\
\hline 2. Abstract & $\begin{array}{l}\text { Provide a structured summary of objectives, perspective, setting, methods (including study } \\
\text { design and inputs), results (including base case and uncertainty analyses), and } \\
\text { conclusions. }\end{array}$ \\
\hline \multicolumn{2}{|r|}{ T } \\
\hline 3. Background and objectives & Provide an explicit statement of the broader context for the study. \\
\hline \multicolumn{2}{|l|}{ Methods } \\
\hline 4. Target population and subgroups & $\begin{array}{l}\text { Describe characteristics of the base case population and subgroups analysed, including } \\
\text { why they were chosen. }\end{array}$ \\
\hline 5. Setting and location & State relevant aspects of the system(s) in which the decision(s) need(s) to be made. \\
\hline 6. Study perspective & Describe the perspective of the study and relate this to the costs being evaluated. \\
\hline 7. Comparators & Describe the interventions or strategies being compared and state why they were chosen. \\
\hline 8. Time horizon & $\begin{array}{l}\text { State the time horizon(s) over which costs and consequences are being evaluated and say } \\
\text { why appropriate. }\end{array}$ \\
\hline 9. Discount rate & $\begin{array}{l}\text { Report the choice of discount rate(s) used for costs and outcomes and say why } \\
\text { appropriate. }\end{array}$ \\
\hline 10. Choice of health outcomes & $\begin{array}{l}\text { Describe what outcomes were used as the measure(s) of benefit in the evaluation and their } \\
\text { relevance for the type of analysis performed. }\end{array}$ \\
\hline 11. Measurement of effectiveness & $\begin{array}{l}\text { Single study-based estimates: Describe fully the design features of the single effectiveness } \\
\text { study and why the single study was a sufficient source of clinical effectiveness data. } \\
\text { Synthesis-based estimates: Describe fully the methods used for identification of included } \\
\text { studies and synthesis of clinical effectiveness data. }\end{array}$ \\
\hline $\begin{array}{l}\text { 12. Measurement and valuation of preference } \\
\text { based outcomes }\end{array}$ & If applicable, describe the population and methods used to elicit preferences for outcomes. \\
\hline 13. Estimating resources and costs & $\begin{array}{l}\text { Single study-based economic evaluation: Describe approaches used to estimate resource } \\
\text { use associated with the alternative interventions. Describe primary or secondary research } \\
\text { methods for valuing each resource item in terms of its unit cost. Describe any adjustments } \\
\text { made to approximate to opportunity costs. } \\
\text { Model-based economic evaluation: Describe approaches and data sources used to } \\
\text { estimate resource use associated with model health states. Describe primary or secondary } \\
\text { research methods for valuing each resource item in terms of its unit cost. Describe any } \\
\text { adjustments made to approximate to opportunity costs. }\end{array}$ \\
\hline 14. Currency, price date, and conversion & $\begin{array}{l}\text { Report the dates of the estimated resource quantities and unit costs. Describe methods for } \\
\text { adjusting estimated unit costs to the year of reported costs if necessary. Describe methods } \\
\text { for converting costs into a common currency base and the exchange rate. }\end{array}$ \\
\hline 15. Choice of model & $\begin{array}{l}\text { Describe and give reasons for the specific type of decision-analytical model used. } \\
\text { Providing a figure to show model structure is strongly recommended. }\end{array}$ \\
\hline 16. Assumptions & $\begin{array}{l}\text { Describe all structural or other assumptions underpinning the decision-analytical model. } \\
\text { Describe all analytical methods supportin the evaluation. This could include methods for }\end{array}$ \\
\hline 17. Analytical methods & $\begin{array}{l}\text { pooling data; approaches to validate or make adjustments (such as half cycle corrections) } \\
\text { to a model; and methods for handling population heterogeneity and uncertainty. }\end{array}$ \\
\hline \multicolumn{2}{|r|}{ 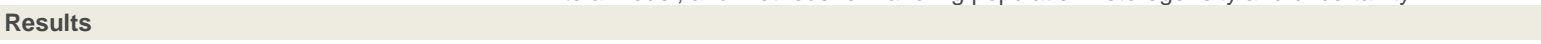 } \\
\hline 18. Study parameters & $\begin{array}{l}\text { Report the values, ranges, references, and, if used, probability distributions for all } \\
\text { parameters. Report reasons or sources for distributions used to represent uncertainty } \\
\text { where appropriate. Providing a table to show the input values is strongly recommended. } \\
\text { For each intervention, report mean values for the main categories of estimated costs and }\end{array}$ \\
\hline 19. Incremental costs and outcomes & $\begin{array}{l}\text { outcomes of interest, as well as mean differences between the comparator groups. If } \\
\text { applicable, report incremental cost-effectiveness ratios. }\end{array}$ \\
\hline 20. Characterising uncertainty & $\begin{array}{l}\text { Single study-based economic evaluation: Describe the effects of sampling uncertainty for } \\
\text { the estimated incremental cost and incremental effectiveness parameters, together with } \\
\text { the impact of methodological assumptions (such as discount rate, study perspective). } \\
\text { Model-based economic evaluation: Describe the effects on the results of uncertainty for all } \\
\text { input parameters, and uncertainty related to the structure of the model and assumptions. } \\
\text { If applicable, report differences in costs, outcomes, or cost-effectiveness that can be }\end{array}$ \\
\hline 21. Characterising heterogeneity & $\begin{array}{l}\text { explained by variations between subgroups of patients with different baseline } \\
\text { characteristics or other observed variability in effects that are not reducible by more } \\
\text { information. }\end{array}$ \\
\hline \multicolumn{2}{|r|}{ 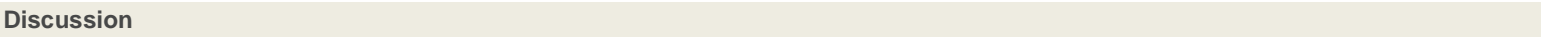 } \\
\hline $\begin{array}{l}\text { 22. Study findings, limitations, generalisability, } \\
\text { and current knowledge }\end{array}$ & $\begin{array}{l}\text { Summarise key study findings and describe how they support the conclusions reached. } \\
\text { Discuss limitations and the generalisability of the findings and how the findings fit with } \\
\text { current knowledge. }\end{array}$ \\
\hline \multicolumn{2}{|r|}{ 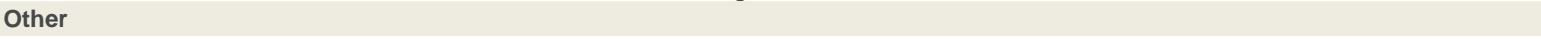 } \\
\hline 23. Source of funding & $\begin{array}{l}\text { Describe how the study was funded and the role of the funder in the identification, design, } \\
\text { conduct, and reporting of the analysis. Describe other non-monetary sources of support. } \\
\text { Describe any potential for conflict of interest of study contributors in accordance with }\end{array}$ \\
\hline 24. Conflicts of interest & $\begin{array}{l}\text { journal policy. In the absence of a journal policy, we recommend authors comply with } \\
\text { International Committee of Medical Journal Editors recommendations. }\end{array}$ \\
\hline
\end{tabular}




\section{Appendix Table 2- Quality assessment}

\begin{tabular}{|c|c|c|c|c|c|c|c|c|c|c|c|c|c|c|c|c|}
\hline & $\begin{array}{l}\text { Economic evaluation } \\
\text { checklist/ Study name }\end{array}$ & $\begin{array}{l}\text { Field et al } \\
\text { (1995) }\end{array}$ & $\begin{array}{l}\text { Langham } \\
\text { et al (1996) }\end{array}$ & $\begin{array}{l}\text { Lindholm } \\
\text { et al (1996) }\end{array}$ & $\begin{array}{l}\text { Wonderling } \\
\text { et al (1996 } \\
\text { a) }\end{array}$ & $\begin{array}{l}\text { Wonderling } \\
\text { et al (1996 } \\
\text { b) }\end{array}$ & $\begin{array}{l}\text { Finkelstein } \\
\text { (2002) }\end{array}$ & $\begin{array}{l}\text { Yosefy et } \\
\text { al (2003a) }\end{array}$ & $\begin{array}{l}\text { Yosefy et al } \\
\text { (2003b) }\end{array}$ & $\begin{array}{l}\text { Finkelstein } \\
\text { et al (2006) }\end{array}$ & $\begin{array}{l}\text { Yosefy et al } \\
\text { (2007) }\end{array}$ & $\begin{array}{l}\text { Department } \\
\text { of Health, } \\
\text { UK (2008) }\end{array}$ & $\begin{array}{l}\text { Mistry et al } \\
\text { (2012) }\end{array}$ & $\begin{array}{l}\text { Sovic et al } \\
\text { (2013) }\end{array}$ & $\begin{array}{l}\text { Schuetz et } \\
\text { al (2013) }\end{array}$ & $\begin{array}{l}\text { Aljutaili et } \\
\text { al (2014) }\end{array}$ \\
\hline 1 & Title & done & done & done & done & done & done & not done & done & done & done & done & done & done & done & done \\
\hline 2 & Study perspective & not clear & not clear & done & not clear & not clear & not clear & not clear & not clear & not clear & not clear & done & done & done & done & not clear \\
\hline 3 & Time horizon & done & done & done & not clear & done & done & not clear & done & done & done & done & done & done & done & done \\
\hline 4 & Discount rate & done & not clear & done & not clear & not clear & done & done & done & done & done & done & done & done & done & done \\
\hline 5 & $\begin{array}{l}\text { Choice of health } \\
\text { outcomes }\end{array}$ & done & done & done & done & done & done & done & done & done & done & done & done & done & done & done \\
\hline 6 & $\begin{array}{l}\text { Measurement of } \\
\text { effectiveness }\end{array}$ & done & done & not clear & done & done & done & done & done & done & done & done & done & done & done & done \\
\hline 7 & $\begin{array}{l}\text { Estimating resources } \\
\text { and costs }\end{array}$ & done & done & done & done & done & done & not clear & done & done & done & done & done & done & done & done \\
\hline 8 & $\begin{array}{l}\text { Currency, price data, } \\
\text { and conversion }\end{array}$ & done & not clear & done & done & not clear & not clear & not done & done & done & done & done & done & done & done & done \\
\hline 9 & Choice of model & done & done & done & done & done & done & not clear & not clear & done & done & done & done & done & done & done \\
\hline 10 & Assumption & not clear & not clear & done & not clear & done & done & not clear & done & done & done & done & done & done & done & done \\
\hline 12 & Study parameters & not clear & done & not done & done & done & done & not done & not done & done & not clear & done & done & done & done & done \\
\hline 13 & $\begin{array}{l}\text { Incremental costs and } \\
\text { outcomes }\end{array}$ & done & done & not clear & done & done & done & not done & not done & done & done & done & done & done & done & done \\
\hline 14 & $\begin{array}{l}\text { Characterising } \\
\text { uncertainty }\end{array}$ & not done & not done & not clear & not clear & not done & not done & not done & not done & done & not clear & done & done & done & done & done \\
\hline \multirow[t]{2}{*}{15} & $\begin{array}{l}\text { Characterising } \\
\text { heterogeneity }\end{array}$ & done & done & not done & done & done & not done & not done & not done & not done & not done & done & done & done & done & done \\
\hline & Overall Score & $\begin{array}{l}\text { moderate } \\
\text { quality }\end{array}$ & $\begin{array}{l}\text { moderate } \\
\text { quality }\end{array}$ & $\begin{array}{l}\text { moderate } \\
\text { quality }\end{array}$ & $\begin{array}{l}\text { moderate } \\
\text { quality }\end{array}$ & $\begin{array}{l}\text { moderate } \\
\text { quality }\end{array}$ & $\begin{array}{l}\text { moderate } \\
\text { quality }\end{array}$ & $\begin{array}{l}\text { low } \\
\text { quality }\end{array}$ & $\begin{array}{l}\text { moderate } \\
\text { quality }\end{array}$ & $\begin{array}{l}\text { high } \\
\text { quality }\end{array}$ & $\begin{array}{l}\text { moderate } \\
\text { quality }\end{array}$ & $\begin{array}{l}\text { high } \\
\text { quality }\end{array}$ & $\begin{array}{l}\text { high } \\
\text { quality }\end{array}$ & $\begin{array}{l}\text { high } \\
\text { quality }\end{array}$ & $\begin{array}{l}\text { high } \\
\text { quality }\end{array}$ & $\begin{array}{l}\text { high } \\
\text { quality }\end{array}$ \\
\hline
\end{tabular}


Appendix Table 3- Characteristics of the CVD Risks Assessment and Management Programme

\begin{tabular}{|c|c|c|c|c|c|c|c|c|c|c|c|c|c|}
\hline & $\begin{array}{l}\text { Field et al } \\
\text { (1995) }\end{array}$ & $\begin{array}{c}\text { Langham } \\
\text { et al } \\
(1996) \\
\end{array}$ & $\begin{array}{c}\text { Lindholm } \\
\text { et al } \\
\text { (1996) } \\
\end{array}$ & $\begin{array}{l}\text { Wonderling } \\
\text { et al (1996 } \\
\text { a) }\end{array}$ & $\begin{array}{l}\text { Finkelstein } \\
\text { (2002) }\end{array}$ & $\begin{array}{c}\text { Finkelstein } \\
\text { et al } \\
(2006) \\
\end{array}$ & $\begin{array}{l}\text { Yosefy et } \\
\text { al (2003a) }\end{array}$ & $\begin{array}{l}\text { Yosefy et } \\
\text { al (2003b) }\end{array}$ & $\begin{array}{c}\text { Department } \\
\text { of Health, } \\
\text { UK (2008) }\end{array}$ & $\begin{array}{l}\text { Mistry et } \\
\text { al (2012) }\end{array}$ & $\begin{array}{c}\text { Sovic et al } \\
\text { (2013) }\end{array}$ & $\begin{array}{l}\text { Schuetz et } \\
\text { al (2013) }\end{array}$ & $\begin{array}{l}\text { Aljutaili et } \\
\text { al (2014) }\end{array}$ \\
\hline \multicolumn{14}{|l|}{ Risk Factors Screened } \\
\hline $\mathrm{BMI}$ & $v$ & $v$ & & $v$ & $v$ & $v$ & v & $v$ & v & $v$ & $v$ & $v$ & \\
\hline Blood pressure & v & v & v & v & v & v & v & v & v & v & v & v & \\
\hline Smoking & v & v & v & v & v & v & v & v & v & v & v & v & \\
\hline Alcohol & $\mathrm{v}$ & $\mathrm{v}$ & & & & & & & & & & & \\
\hline Physical activity & & $v$ & & & $v$ & $v$ & & & $v$ & $v$ & v & $v$ & \\
\hline Family history of CVD & v & v & & v & v & v & & v & v & v & $\mathrm{v}$ & v & \\
\hline Diet & v & v & & & & & & & & v & v & & \\
\hline Blood cholesterol & $v$ & v & v & $v$ & $v$ & $v$ & $v$ & $v$ & $v$ & $v$ & $v$ & $v$ & \\
\hline Blood glucose & & & & v & v & v & v & & v & v & v & v & \\
\hline Not Sure & & & & & & & & & & & & & $\mathrm{v}$ \\
\hline \multicolumn{14}{|l|}{ Additional Intervention } \\
\hline Follow up & $v$ & $v$ & $v$ & $v$ & $v$ & $v$ & $v$ & $v$ & $v$ & $v$ & $v$ & $v$ & $v$ \\
\hline $\begin{array}{l}\text { Advice on reducing risk } \\
\text { factors }\end{array}$ & v & & $v$ & & v & $v$ & $v$ & $v$ & v & $v$ & $\mathrm{v}$ & $v$ & $v$ \\
\hline Drug prescription & v & & & & $v$ & $\mathrm{v}$ & $\mathrm{v}$ & $\mathrm{v}$ & $\mathrm{v}$ & $\mathrm{v}$ & v & v & v \\
\hline Physical activity & & & & & v & v & v & v & v & & & v & v \\
\hline Nutrition/Diet/Weight loss & & & $v$ & & v & v & v & v & v & & & v & v \\
\hline Smoking cessation & & & & & v & v & v & v & v & v & v & v & v \\
\hline \multicolumn{14}{|l|}{ Health Care Provider } \\
\hline Nurse led & v & v & & v & & & & & $v$ & $v$ & $\mathrm{v}$ & $v$ & \\
\hline physician lead & & & & & & & v & & v & & & v & \\
\hline Nurse + Physician & & & & & & & & $v$ & & & & & \\
\hline Not Sure & & & v & & v & v & & & & & & & v \\
\hline \multicolumn{14}{|l|}{ Location of Screening } \\
\hline General practice and hospital & $v$ & $v$ & $v$ & $v$ & & & $v$ & & $v$ & $v$ & $v$ & $v$ & \\
\hline $\begin{array}{l}\text { Also in other community } \\
\text { centres }\end{array}$ & & & & & $v$ & $v$ & & $v$ & & & & & \\
\hline Not Sure & & & & & & & & & & & & & v \\
\hline \multicolumn{14}{|l|}{ Comparators } \\
\hline Usual care & & v & v & v & & v & v & v & v & v & v & v & v \\
\hline Other alternatives & $\mathrm{v}$ & & & & v & & & & v & & & v & v \\
\hline
\end{tabular}


